\title{
PRODUCTION OF CARDED COMPACT COTTON YARN OF COMPARABLE QUALITY TO THE COMBED CONVENTIONAL RING YARN
}

\author{
SANAD, SUZAN H. ${ }^{1}$ H. E. M. MAHMOUD ${ }^{2}$ AND M.A.M. EL-SAYED ${ }^{1}$ \\ 1. Cotton Research Institute. Agric. Res. Center, Giza, Egypt. \\ 2. Faculty of Applied Arts, Mansoura Univ.
}

(Manuscript received 10 October 2010)

\begin{abstract}
The objective of this study was to determine the influence of cotton type in order to find out if it is possible to produce a carded compact yarn of comparable quality to the combed conventional yarn. Marzoli spinning frame was used to produce combed and carded cotton yarns with linear densities of 14.76 tex (40 Ne), 19.68 tex $(30 \mathrm{Ne})$, and 29.53 tex $(20 \mathrm{Ne})$, were manufactured from the same LS cotton (Giza 80 and Giza 90, as Egyptian cotton and MLS, Greece "Upland" cotton. Combing was carried out 18\% noils during the combing process. Within the tests carried out, the following quality parameters were analyzed of fiber and yarn quality properties such as single yarn strength, elongation, mass irregularity, yarn faults, and hairiness.

Yarns spun on the Olfil carded compact spinning frame were found to have the following advantages when compared to those spun on the combed ring spinning frame: higher strength and elongation at break, somewhat equivalent or higher yarn unevenness, and a significantly lower number of yarn faults such as thin, thick places and neps, as well as a lower hairiness. This study also revealed that compact spinning could be used for producing coarse and medium yarn counts from 20's to 40's, from Long staple Egyptian cotton with comparable quality to the combed conventional ring spun yarns .
\end{abstract}

\section{INTRODUCTION}

The main goal of any spinning company is to achieve improved yarn quality that will ensure better competitiveness and higher price. Therefore, it was felt useful to compare the quality of conventional and compact spun yarns so as taking into account the production costs, to explore whether the quality parameters of compact yarns are improved significantly enough to justify the purchase of new machines, or a clapping of drafting equipment of the existing ring spinning frames.

Compact spinning is a revolution in spinning technology. Over recent years, the system of compact spinning has constituted a rapidly developing technological trend in most countries. The spinning triangle that occurs while the yarn is formed is the reason why many fibers leave the drafting roving, or become partly spun into the 
yarn with one end only. This causes a greater waste of fibers, a lower exploitation of fiber tenacity in yarn, a poorer appearance and a greater hairiness of the spun yarn, (Nicolic et al. 2003).

Compact spinning forms fibers into a narrow sliver by drafting in a virtually tension-free process within a compacting zone. The compact sliver is twisted in a very small spinning triangle, thereby eliminating peripheral fibers, (Artzt 2000).

The compact spinning system enables nearly all of the fibers to be twisted. Thus, the enhanced incorporation of the fiber characteristics into the yarn structure would allow optimal exploitation of the raw material with increased yarn strength. Since the compact spinning system has been introduced commercially onto the market, a large number of studies have been conducted related to the short-staple and long-staple compact spinning techniques, each of which claims to offer advantages, dramatically increased production speeds, (Artzt, 1997,Olbrich, 2000; Stalder, 2000 El-Sayed and Sanad 2007).

The end breaks in compact spinning are approx. 50\% fewer, which permits the reduction of the number of fibers in the cross-section, or to spin a finer yarn count. Reducing the possibility of the number of fibers in the cross-section enables the use of lower-priced tops with coarser fibers. Campen (2002). Çelik and Kadoğlu (2004), reported that In compact yarns, fibers are uniformly oriented and joined into the yarn right after the end of the drafting arrangement. Therefore, better tenacity, elongation, and hairiness properties can be ensured. The better tenacity properties of compact spun yarn provide opportunities to work with lower twist coefficients, resulting in an increase in production rate, and also better handling properties of the end-product

To compare the yarn parameters obtained from conventional ring-spinning frame with those produced by compact spinning; Krifa and Ethridge (2003) reported that the compact spinning technology has the potential of improving both the quality and profitability aspects of cotton yarn manufacturing. Depending on the objectives of the textile manufacturer, different approaches are available. One approach could be to reduce the cost of the raw fiber while maintaining yarn quality. Another could be reducing twist while using the same raw fiber. Yet another - as emphasized in this report - is to eliminate some or all of the combing while still producing acceptable yarn quality. According to expert estimates (Egbers, 1999). The combing operations account for nearly $9 \%$ of the total production cost of a $30 \mathrm{Ne}$ combed cotton yarn. This represents approximately $21 \%$ of the processing cost. While the compact technology is promising, there are still major questions to be answered. These include the following: 
- In order to produce a carded compact yarn with comparable performance to the combed conventional one, what type of raw cotton fiber should be used?

- Do the fiber quality requirements vary depending on the yarn production sequence? If so, what are the fiber properties that are most crucial for the alternative process?

- Is it possible to overcome yarn evenness problems by optimizing the preparation (especially carding) or by selecting raw fiber with specific parameters?

- Given the new, enhanced structure of compact yarns, are these evenness defects as critical as they were for the conventional yarns?

The main objective of this study was to investigate the influence of cotton type in order to produce a carded compact yarn with comparable performance to the combed conventional one

\section{MATERIALS AND METHODS}

Giza 80 and Giza 90 as Long Staple Egyptian Cottons, and a Medium Long Staple Upland Greece cotton, were manufactured to combed and carded yarns on both the compact and the conventional spinning frame "Olfil RST1 Marzoli machine, Two in One". The linear densities of the spun yarns obtained were 14.76 tex (40 Ne), 19.68 tex $(30 \mathrm{Ne})$, and 29.53 tex $(20 \mathrm{Ne})$. The carded and combed yarns were manufactured from the same cotton, the eliminated $18 \%$ of noils during combing process.

Within this research work, the quality parameters of the fibers were tested, using the HVI and Micromat testers. The spun yarns were tested for the following parameters: single yarn strength "cN/tex", yarn strength c.v. "\%" elongation at break "\%" using Statimat ME. Mass irregularity, hairiness, and yarn faults were also measured via Uster Tester 3, at a yarn feeding of $400 \mathrm{~m} / \mathrm{min}$. The obtained results of yarn quality parameters were compared with the Uster Statistics, (2007). Fiber quality parameters from the three cottons obtained from the HVI and Micromat testers are presented in Table 1. 
Table1. HVI and Micromat fiber data of the raw cotton

\begin{tabular}{|l|c|c|c|}
\hline Fiber Properties & Giza 80 & Giza 90 & $\begin{array}{c}\text { Upland cotton } \\
\text { (Greece) }\end{array}$ \\
\hline Upper Half Mean (mm.) & 31.0 & 30.0 & 27.8 \\
\hline Uniformity Index (\%) & 85.6 & 85.5 & 79.2 \\
\hline Strength (cN/Tex) & 38.4 & 37.8 & 33.5 \\
\hline Elongation (\%) & 7.4 & 7.5 & 7.4 \\
\hline Short Fibers (\%) & 5.7 & 6.3 & 10.2 \\
\hline Micronaire value & 4.2 & 4.1 & 4.1 \\
\hline Maturity & 0.94 & 0.92 & 0.83 \\
\hline Fineness (milltex) & 167 & 153 & 155 \\
\hline Reflectance (Rd\%) & 63.7 & 65.7 & 73.4 \\
\hline Yellowness (+b) & 12.6 & 11.8 & 9.4 \\
\hline
\end{tabular}

The obtained data were subjected to statistical analysis in completely randomized factorial design with six replications according to Draper and Smith 1966.

\section{RESULTS AND DISCUSSION}

\section{Yarn strength and elongation}

Data in table 2 indicated that the difference in single yarn strength between carded compact yarns and the conventional combed ring yarns was not statistically insignificant. For all cotton varieties, the single yarn strength and elongation (\%) values of compact carded yarns were slightly higher than those of the conventional combed ring yarns. The evaluations of statistical analysis results of the difference of two systems were significant, as shown in Table 3.

Table 2. Mean values ( 3 counts and 3 varieties) of yarn quality properties, combed conventional vs. carded compact.

\begin{tabular}{|l|l|c|c|c|c|c|c|c|c|}
\hline & & $\begin{array}{c}\text { Strength } \\
(\mathrm{cN} / T e x)\end{array}$ & $\begin{array}{c}\text { CV Strength } \\
(\%)\end{array}$ & $\begin{array}{c}\text { Elongation } \\
(\%)\end{array}$ & $\begin{array}{c}\text { Eveness } \\
(\text { C.V \%) }\end{array}$ & $\begin{array}{c}\text { Thin } \\
\text { places }\end{array}$ & $\begin{array}{c}\text { Thick } \\
\text { places }\end{array}$ & $\begin{array}{c}\text { Neps } \\
\text { Hairine } \\
\text { ss }\end{array}$ \\
\hline \multirow{2}{*}{ Ring } & Carded & 19.00 & 7.03 & 5.2 & 12.54 & 30 & 67 & 52 & 4.04 \\
\cline { 2 - 10 } & Combed & 19.95 & 6.27 & 5.7 & 11.42 & 22 & 32 & 29 & 3.65 \\
\hline \multirow{2}{*}{ Compact } & Carded & 20.13 & 6.03 & 6.2 & 12.09 & 13 & 51 & 48 & 3.73 \\
\cline { 2 - 10 } & Combed & 21.89 & 5.3 & 6.2 & 11.31 & 7 & 23 & 24 & 3.42 \\
\hline
\end{tabular}

When single yarn strength was examined, there was an important difference between compact and conventional ring yarns which were produced from the three 
cotton varieties under the studied three yarn counts. The compact-spun yarns' strength and elongation (\%) values are higher than the conventional ones. In this respect, Giza 80 and Giza 90 Egyptian Long staple cotton showed higher strength and elongation (\%) than the Upland cotton. Thus, it appears that the ability of compact spinning to compensate for the beneficial effect of combing as it tends to reduce the short fibers and increase the orientation of the fibers and eliminates many impurities and seed coat fragments remaining in the fiber after the carding process.

The differences between the two spinning systems were found to be significant with regard to single yarn strength and elongation (\%) values for 20's, 30's and 40's yarns. Thus, compact spinning made it possible to produce a 20's, 30's and 40 's Ne carded yarn having tensile properties comparable to those of a combed yarn spun on the conventional frame. Furthermore, yarn hairiness levels were significantly lower for a great majority of the compact spun yarns. A lower difference in yarn strength and elongation (\%) between the carded compact yarns and combed conventional yarns produced on the ring spinning machine can be explained with the construction of the drafting system that enables maximum fiber condensation all the way up to the clamping line in the compact drafting system.

Comparison of the obtained yarn quality parameters obtained with the Uster Statistics (2007) presented in Figures 1 and 2 which depict the differences in the levels of single yarn strength between the compact carded yarn and the conventional combed ring yarn compared with Uster Statistics in both different cotton varieties and yarn counts. It could be stated that the individual parameters have reached the following levels.

- single yarn strength of compact carded yarns of Giza 80 and Giza 90 below 5\%, while Upland compact carded yarn was at the level of $25 \%$.

- Ne 20's and 30's for all cotton varieties substantially below or equivalent at the level of $5 \%$, while $\mathrm{Ne} 40$ 's compact carded yarn recorded the same level of $25 \%$.

This revealed distinct patterns, depending on the cottons, and the differences between the two processing sequences. Among the three cottons under study, Giza 80 and Giza 90 showed a carded compact yarns with equivalent or higher strength levels than the combed conventional ones.

\section{Yarn evenness}

The carded compact spun yarns had higher yarn unevenness values irregularity, thin and thick places and nep values, than the conventional combed ring spun yarns for all cotton types and consequently yarn counts as shown in in Tables 3 and 4. 
The Uster evenness CV\%, thin and the thick place values of both compact carded yarns and conventional combed ones were found to have a statistically significant difference for all cotton types "Giza 80, Giza 90 and Upland cotton" and yarn counts "20's, 30's and 40's" (Tables 3 and 4 and Figures 3 and 42). Giza 80 and Giza 90 were somewhat higher evenness than Upland cotton

The differences of compact-spun and conventionally-spun yarns which were produced from both cotton types and yarn counts, in terms of the Uster Statistics (2007) were presented in Figures 3 and 4.

In this respect Krifa and Ethridge (2003) explained that in addition to removing short fibers, the combing operation eliminates many impurities remaining in the fiber after the carding process. Some of these, are fiber neps and seed-coat fragments (SCFs), are known to significantly deteriorate yarn evenness and increase its defects (Krifa et al., 1999; 2000). Without combing, these particles remain problematic, and the compact spinning is not likely to overcome them. It is not surprising, then, that the carded compact yarns did not compare favorably to the combed conventional yarn when considering the evenness aspect. As shown in Figures 3 and 4 . The differences between the compact carded yarn and the conventional combed ring yarn compared with Uster Statistics in both different cotton varieties and yarn counts which could be stated that:

- Mass variation "evenness CV\%" of compact carded yarns of Giza 80 and Giza 90 was between $25 \%$ and $50 \%$, while Upland compact carded yarn was at the level of higher than $50 \%$;

- With regard to yarn count, Ne 20's, 30's and 40's for all cotton varieties were substantially below or equivalent to the level of $50 \%$.

These evenness results could limit the application of carded compact yarns in traditionally combed yarn markets. However, there are ways to improving the evenness problem, meaning that using Egyptian Long Staple cotton varieties which characterized by lower short fiber index and higher maturity.

\section{Yarn hairiness}

The Uster hairiness $(\mathrm{H})$ of carded compact yarns is significantly higher when compared with the hairiness of conventional ring combed yarns in both cotton types and yarn counts (Tables 3 and 4).

Comparison of the obtained yarn hairiness obtained with the Uster Statistics (2007) presented in Figures 5 and 6 which depicted in the differences levels between the compact carded yarn and the conventional ring combed yarn compared with Uster Statistics in both different cotton varieties and yarn counts it could be stated that;

- Yarn hairiness of compact carded yarns of Giza 80 and Giza 90 and Upland cottons were below $5 \%$ Uster level 
- With regard to yarn count, $\mathrm{Ne} 20^{\prime} \mathrm{s}$ and 30's for all cotton varieties were substantially below the level of $5 \%$, while in 40 's yarn count the conventional ring combed yarn was equivalent of $5 \%$ Uster level, on the other hand, 40 's compact carded yarns was substantially below the level of $25 \%$.

\section{REFERENCES}

1. Artzt P., International Textile Bulletin, 1997, Vol. 2, p. 41-48.

2. Artzt, P. 2000. The special structure of compact yarns - advantages in downstream processing. Proceedings of the Beltwide Cotton Conference Volume 1:798-803 2000. National Cotton Council, Memphis, TN.

3. Campen W., Melliand English, 2002, Vol. 6, p. E82-E83.

4. Çelik, P. and Kadoğlu, H. 2004. A research on the compact spinning for long staple yarns. Fibres \& textiles in Eastern Europe October / December 2004, Vol. 12 , No. 4 (48).

5. Draper, N. R., and R. Smith. 1966. Applied regression analysis. John Wiley and Sons, Inc., New York. 704 Pp.

6. Egbers G., 1999. The Future of Spinning and Weaving. Melliand International: No. 1: 8+, 4 pages (Mar. 1999).

7. El-Sayed, M.A.M. and Suzan H. Sanad. 2007. The impact of new spinning technologies on the Egyptian cottons. Autex Res. Journal, Vol.8, No.4, December 2007.

8. Krifa, M and Ethridge, D. 2003. Compact ring spun yarns: an examination of some productivity issues. Textile Topics Vol: 2003-2, (Spring 2003).

9. Krifa M., Gourlot J.-P. and Dréan J.-Y., 1999. Seed-Coat Fragments, a major source of cotton yarn imperfections. Beltwide Cotton Conferences, January 3-7, Orlando, FL, National Cotton Council of America. Memphis, TN, pp. 722-724.

10. Krifa M., Vydelingum V., Gourlot J.-P. and Frydrych R., 2000. Seed-Coat Fragments effect on carded cotton yarn evenness. Beltwide Cotton Conferences, January 4-8, San Antonio, TX, National Cotton Council of America. Memphis, TN, pp. 1538-1541.

11. Nikolic M, Stjepanovic Z, Lesjak F, Stritof A., Fibres \& Textiles in Eastern Europe, Vol. 11, No 4 (43), 2003, p. 30-35.

12. Olbrich A., Melliand English, 2000, Vol. 3, p. E27-E28.

13. Stalder H., Melliand English, 2000, Vol.3, p. E26-E27.

14. Uster Statistics, 2007. 
Table 3. Yarn quality properties of conventional ring, compact for different cotton types.

\begin{tabular}{|c|c|c|c|c|c|c|c|c|c|c|c|c|c|c|c|c|}
\hline \multirow{2}{*}{ 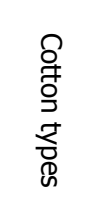 } & \multicolumn{2}{|c|}{$\begin{array}{l}\text { Strength } \\
\text { (cN/Tex) }\end{array}$} & \multicolumn{2}{|c|}{ Cv Strength (\%) } & \multicolumn{2}{|c|}{ Elongation (\%) } & \multicolumn{2}{|c|}{ Eveness (C.V \%) } & \multicolumn{2}{|c|}{ Thin Places } & \multicolumn{2}{|c|}{ Thick places } & \multicolumn{2}{|c|}{ Neps } & \multicolumn{2}{|c|}{ Hairiness } \\
\hline & 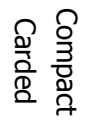 & 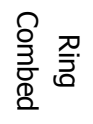 & 疍 & 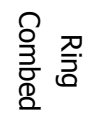 & 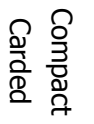 & 呑 & 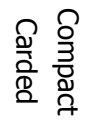 & 总 & 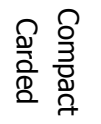 & 总 & 只 & 总 & 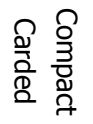 & 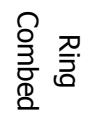 & 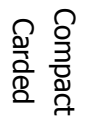 & 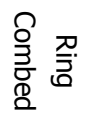 \\
\hline Giza 80 & 21.30 & 21.23 & 5.85 & 5.84 & 6.0 & 5.4 & 11.54 & 11.11 & 13 & 16 & 15 & 13 & 14 & 5 & 3.54 & 3.55 \\
\hline Giza 90 & 20.43 & 20.22 & 5.84 & 6.22 & 6.1 & 5.9 & 11.87 & 11.17 & 11 & 22 & 53 & 15 & 46 & 8 & 3.64 & 3.59 \\
\hline Upland & 18.66 & 18.39 & 6.41 & 6.76 & 6.6 & 5.7 & 12.86 & 11.97 & 16 & 30 & 90 & 69 & 84 & 75 & 4.03 & 3.83 \\
\hline $\begin{array}{l}\text { L.S.D at } \\
5 \% \text { level }\end{array}$ & & \multicolumn{2}{|c|}{1.29} & \multicolumn{2}{|c|}{0.7} & \multicolumn{2}{|c|}{0.27} & \multicolumn{2}{|c|}{4.79} & \multicolumn{2}{|c|}{7.3} & \multicolumn{2}{|c|}{9.44} & \multicolumn{2}{|c|}{0.05} \\
\hline
\end{tabular}

Table 4. Yarn quality properties of conventional ring, compact for different yarn count.

\begin{tabular}{|c|c|c|c|c|c|c|c|c|c|c|c|c|c|c|c|c|}
\hline \multirow{2}{*}{ 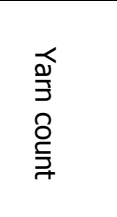 } & \multicolumn{2}{|c|}{$\begin{array}{l}\text { Strength } \\
\text { (cN/Tex) }\end{array}$} & \multicolumn{2}{|c|}{ Cv Strength (\%) } & \multicolumn{2}{|c|}{ Elongation (\%) } & \multicolumn{2}{|c|}{ Eveness (C.V \%) } & \multicolumn{2}{|c|}{ Thin Places } & \multicolumn{2}{|c|}{ Thick places } & \multicolumn{2}{|c|}{ Neps } & \multicolumn{2}{|c|}{ Hairiness } \\
\hline & 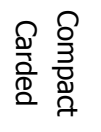 & 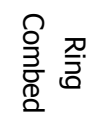 & 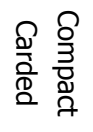 & 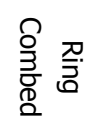 & 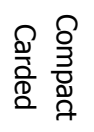 & 导 & 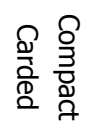 & 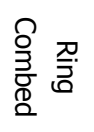 & 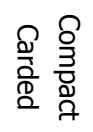 & ס्. & 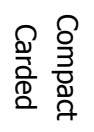 & 导 & 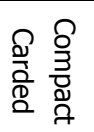 & 㞧 & 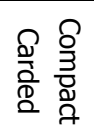 & 导 \\
\hline 20 's & 21.10 & 20.59 & 5.64 & 5.53 & 7.0 & 6.4 & 11.21 & 10.66 & 5 & 5 & 15 & 8 & 6 & 2 & 3.52 & 3.4 \\
\hline 30's & 20.25 & 20.29 & 6 & 6.26 & 6.3 & 5.6 & 12.19 & 11.51 & 14 & 26 & 55 & 34 & 62 & 32 & 3.57 & 3.65 \\
\hline 40 's & 19.07 & 18.96 & 6.46 & 7.03 & 5.5 & 5.0 & 12.87 & 12.07 & 21 & 37 & 84 & 54 & 77 & 54 & 4.12 & 3.91 \\
\hline $\begin{array}{l}\text { L.S.D at } \\
5 \% \text { level }\end{array}$ & \multicolumn{2}{|c|}{0.45} & \multicolumn{2}{|c|}{1.29} & \multicolumn{2}{|c|}{0.7} & \multicolumn{2}{|c|}{0.27} & \multicolumn{2}{|c|}{4.79} & \multicolumn{2}{|c|}{7.3} & \multicolumn{2}{|c|}{9.44} & \multicolumn{2}{|c|}{0.05} \\
\hline
\end{tabular}



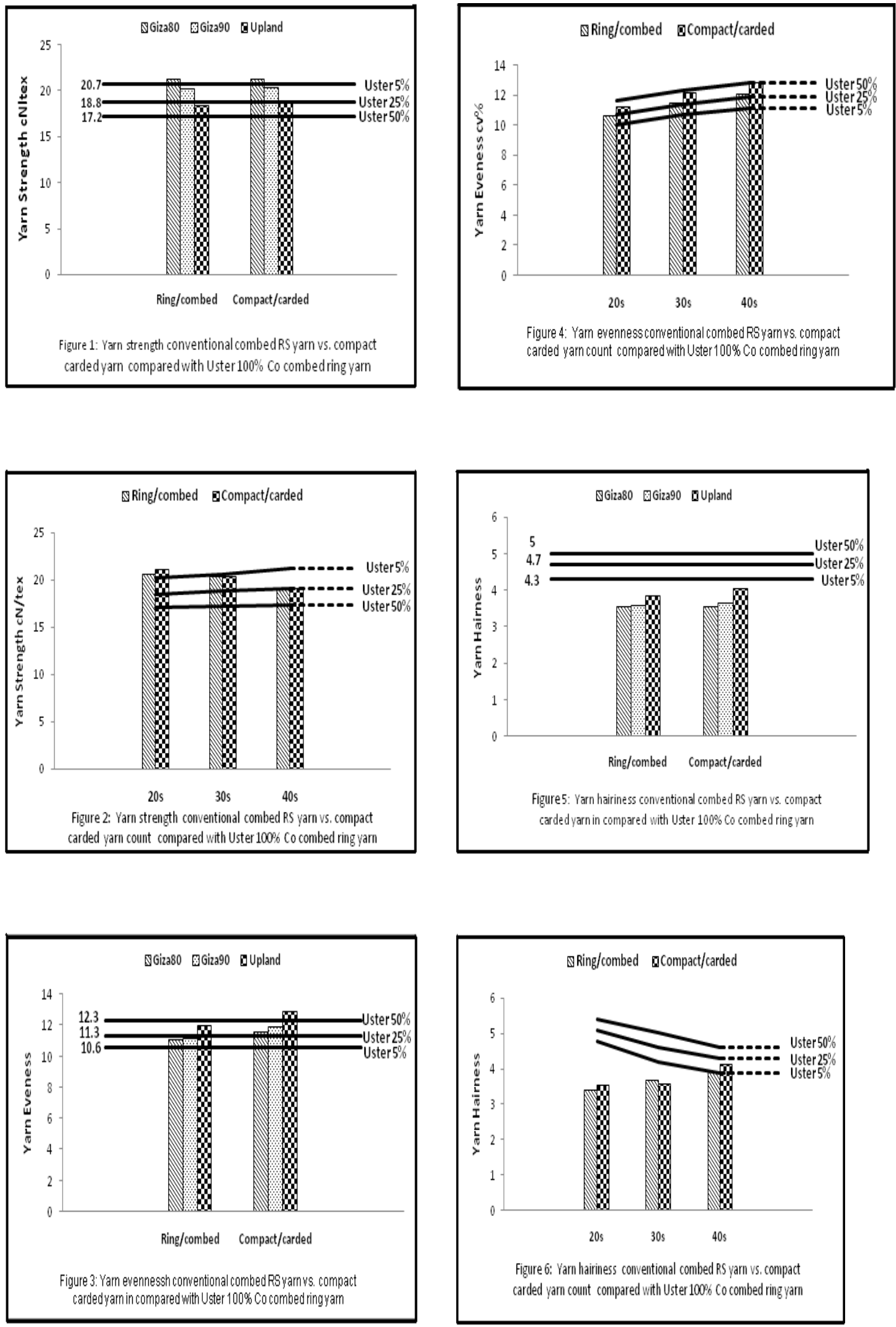


\section{انتاج خيوط غزل مدمج مسرحة منافسة فى جودتها للخيوط الممشطة المغزولة حلقيا}

سوزان حسينى سند' ، حسام الاين محمد محمود' ، محمد عبد الرحمن محمد السيد'

$$
\text { r r ـ ـ كعة بحوث القطن - مركز البحوث الزر اعية - الجبزة }
$$

الهدف من هذه الدراسة هو انتاج خيوط غزل مدمج مسرحة منافسة فى جودتها للخيوط المشطة المغزولة حلقيا على نفس النمر الغزلية ـ استخدم لهذه الدراسة صنفى القطن المصرى جيزة 80 وجيزة 90 من طبقة اقطان طويل التيلة قبلى وصنف قطن ابلند يونانى لإنتاج نمر غزلية 20 و 30

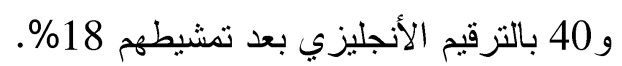

تم تحليل ودر اسة خو اص جودة التيلة وخواص جودة خيوط الغزل المتمنلة فى متانة

و استطالة الخيط المفرد ، الأنتظام كعيوب الخيط و التشعير ـ و اظهرت النتائج ان الخيوط المسرحة

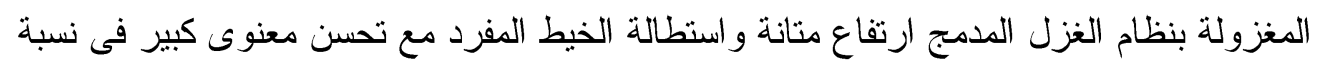

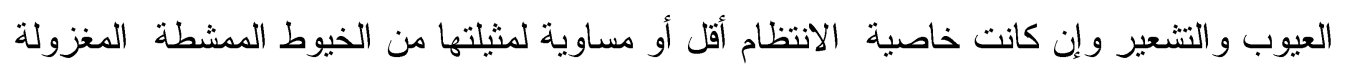
حلقيا ـ ومن أهم النتائج المتحصل عليها هو إنتاج خيوط غزل غزل المدمج مسرحة على نمر متوسطة

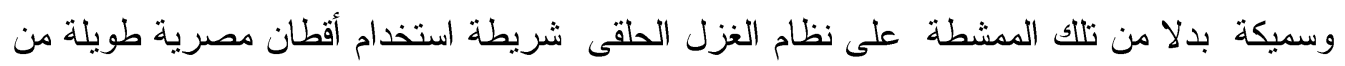

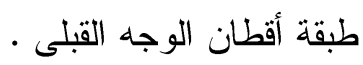

